The Philosophical Journal of Conflict and Violence

Vol. I, Issue $1 / 2017$

(C) The Authors, 2017

Available online at http://trivent-publishing.eu/

\title{
War and Peace in Plato's Political Thought
}

\author{
Joan-Antoine MALLET \\ Université Paul-Valéry Montpellier 3 (France), CRISES EA 4424 \\ Centre de recherches interdisciplinaires en sciences humaines et sociales de Montpellier
}

\begin{abstract}
In Ancient Greece, the relation between war and peace used to have an ambiguous meaning. War was considered as a normal state and peace was seen only as an exception or a temporary truce during a long lasting conflict. But peace and political stability were also valued: the aim of war was never the total annibilation of the opponent. Besides this opposition, there was a balance between war and peace during these times and this conception, inherited from the heroic times, lasted until the beginning of the Peloponnesian $W$ ar. This event redefined the relation between war and peace. The meaning of conflict moved from polemos, as codified conflict between cities, to stasis, as civil war. War was less perceived as something positive and more people valued peace and stability. Plato's political thought was developed in this context as a potential answer to this redefinition of conflict as well as the threat of an excessive and radical conception of war. However, Plato had to face an exigent challenge. No political regime was able to establish peace anymore, so Plato needed to create a brand new political system to solve the problems raised by the Peloponnesian $W$ ar. The goal of this paper will be to present Plato's response to these political challenges by showing that his response is deeply innovative for his time but also profoundly rooted in a traditional conception of conflict that was already obsolete when he wrote his masterpieces.
\end{abstract}

\section{Keywords}

Plato; Republic, polemos; stasis; war; politic; Ancient Greece; Athens; Peloponnesian War

\section{Introduction}

Plato was born in approximately 428/427 BC and died approximately 348/347 BC. He was a citizen of Athens and he was a contemporary of the political and military decline of this city. The main cause of this decline was the Peloponnesian War (431-404) between Athens and its allies (Peloponnesian League) and Sparta and its allies (Delian League). This event radically changed Athens's history because the Peloponnesian War had irremediably weakened Athens's power by causing, within the city, a new form of conflict called "stasis" (often translated, in English, as "civil war"). The main characteristic of stasis is breaking the balance between the different parts of the city and leading the city to violence and injustice.

This is an Open Access article distributed in accordance with the Creative Commons Attribution Non Commercial (CC-BY-NC-ND 4.0) license, which permits others to copy or share the article, provided original work is properly cited and that this is not done for commercial purposes. Users may not remix, transform, or build upon the material and may not distribute the modified material (http:/ / creativecommons.org/ licenses/ by-nc/4.0/) 
Plato witnessed a large part of these tragic events and in his works (especially in the Republic and in the Seventh Letter ${ }^{1}$ ) it is possible to find some profound reflections about the problem of the relation between politics and conflict. This correlation between Athens's history and Plato's philosophy is so striking and distinctive that it leads me to ask the following question: is it possible to assume that Plato has tried, in his philosophy, to address some of the most important and challenging problems caused by the political problems of his time? In other words: has Plato's political philosophy been influenced by the problem of stasis?

To try to answer this question, I will defend the following thesis: Plato understood that stasis represents a brand new conception of conflict for Athens's political system and he developed his political philosophy mainly in order to try to solve this problem. More precisely, I will show that Plato's response to the challenge raised by stasis consists in the elaboration of a new political model of city (called kallipolis and described in the Republic) and in the creation of a class of warriors named "guardians" charged to prevent stasis from happening again.

To defend this thesis, I will proceed according to three main steps. First, I will clarify what were the main political and military problems due to stasis in Plato's time. Then, I will present Plato's response to these problems (especially in the Republic). Finally, I will show the limits of Plato's responses to the problem of stasis.

\section{Plato's vision on Athens's political crisis}

Plato's political thought was influenced by the political changes that occurred in the Greek world between the end of the fifth century and the beginning of the fourth century BC. In this first step, I will point out how these changes deeply influenced Plato.

\section{A. Athens's crisis as a prelude to Plato's political philosophy:}

The Peloponnesian War and its consequences in Athens, the Thirty Tyrants reign, represent a major gap in Athens's history. From this point on, the conception of war and peace in the Greek world radically changed from an ancient one, based on "polemos" (codified war between cities), to a new one based on "stasis" (civil war).

In ancient Greece polemos was a normal state. Even if peace was praised, it was conceived of as a temporary state. War, on the contrary, was a normal aspect of the political life of the cities. Polemos allowed cities to gain power by weakening other cities but followed a strict codification, only happening during a certain part of the year. Polemos was not a war of conquest or of subjugation because no city had the power to totally destroy the other cities. Warriors had to respect a certain code of honor by preventing themselves from enslaving opponents or sacking sanctuaries. To sum up, this kind of conflict used to guarantee stability between cities by preventing one of them from becoming too powerful and dominating the others. ${ }^{2}$

The Peloponnesian War completely challenged this model of polemos and established stasis as a new conception of conflict as total war. Stasis is no longer concerned with showing military ethics or honor. On the contrary, it is focused only on the annihilation of the opponent. This shift is deeply rooted in the political changes that occurred during the fifth century BC. At this time, Athens defeated the Persian armies and established its hegemony on the other Greek cities by creating the Delian League, a military coalition

\footnotetext{
${ }^{1}$ Concerning the authenticity of this work, see Friedrich Solmsen, "Review of Plato's Seventh Letter," Gnomon 41, no. 1 (1969): 29.

2 See Jacqueline de Romilly, "Guerre et Paix Entre Cités," in Problèmes de La Guerre En Grèce Ancienne, ed. Jean-Pierre Vernant (Seuil, 1999), 274-83.
} 
controlled by Athens to increase its power over the other cities. Given the situation, Sparta, as the main opponent to Athens, declared war on Athens in 431. This was the beginning of the Peloponnesian War, which ended in 404 with the defeat of Athens. ${ }^{3}$ This war was crucial in ancient Greek history because, for the first time, conflict happened not between Greek and non-Greek warriors, but amongst Greeks. It is a radical shift from an old system of conflict focused on an exterior enemy (polemos) to a new kind focused on the strife for supremacy amongst Greek cities. This shift caused real trauma for Athens, which was even more significant since the Athenian armies were defeated by Sparta in 404 and a new political regime, the Thirty Tyrants, was established as a replacement to democracy. The Thirty Tyrants took power, murdered the partisans of democracy and spread civil war all over Athens until 403, when democracy was reestablished.

In only half a century, the conception of conflict radically changed. Conflict was no longer about fighting an alien threat but about civil war, war between people sharing the same culture (or, even worse, people from the same city). This context forms the foundation of Plato's political thought and shows how urgent it was to define a new conception of war and peace for Athens in order to avoid a new era of conflicts.

\section{B. Plato's vision about the political situation of his time:}

Plato was a young man just after the Athenian defeat and during the rule of the Thirty Tyrants. By witnessing this tragic era, Plato realized how dangerous stasis could be for the city. From this, he started to elaborate on his own reflections about what should be the best political system for Athens in order to avoid such tragic events from happening again. The core of his reflections about the deep connections between politics, stasis, and philosophy can be found in the Seventh Letter. This letter can be considered as Plato's philosophical biography. In the beginning of this letter, Plato describes his life as a well-born young man in Athens and tells us how he was disgusted by the succession of different political regimes in Athens and by the fact that all of these regimes were unable to fight injustice and violence and, eventually, restore peace:

When I was a young man I had the same ambition as many others: I thought of entering public life as soon as I came of age. And certain happenings in public affairs favored me, as follows. The constitution we then had, being anathema to many, was overthrown; and a new government was set up consisting of fifty-one men, two groups-one of eleven and another of ten-to police the market place and perform other necessary duties in the city and the Piraeus respectively, and above them thirty other officers with absolute powers. Some of these men happened to be relatives and acquaintances of mine, and they invited me to join them at once in what seemed to be a proper undertaking. My attitude toward them is not surprising, because I was young. I thought that they were going to lead the city out of the unjust life she had been living and establish her in the path of justice, so that I watched them eagerly to see what they would do. But as I watched them they showed in a short time that the preceding constitution had been a precious thing. Among their other deeds they named Socrates, an older friend of mine whom I should not hesitate to call the more just man of that time, as one of a group sent to arrest a certain citizen who was to be put to death illegally, planning thereby to make Socrates willy-nilly a party to their actions. But he refused, risking the utmost danger rather than be an

\footnotetext{
${ }^{3}$ See Claude Orrieux and Pauline Schmitt Pantel, Histoire Grecque (PUF, 2004), 211.
} 
associate in their impious deeds. When I saw all this and other like things of no little consequence, I was appalled and drew back from that reign of injustice. Not long afterwards the rule of the Thirty was overthrown and with it the entire constitution; and once more I felt the desire, though this time less strongly, to take part in public and political affairs. Now many deplorable things occurred during those troubled days, and it is not surprising that under cover of the revolution too many old enmities were avenged; but in general those who returned from exile acted with great restraint. By some chance, however, certain powerful persons brought into court this same friend Socrates, preferring against him a most shameless accusation, and one which he, of all men, least deserved. For the prosecutors charged him with impiety, and the jury condemned and put to death the very man who, at the time when his accusers were themselves in misfortune and exile, had refused to have a part in the unjust arrest of one of their friends.

The more I reflected upon what was happening, upon what kind of men were active in politics, and upon the state of our laws and customs, and the older I grew, the more I realized how difficult it is to manage a city's affairs rightly. For I saw it was impossible to do anything without friends and loyal followers; and to find such men ready to hand would be a piece of sheer good luck, since our city was no longer guided by the customs and practices of our fathers, while to train up new ones was anything but easy. And the corruption of our written laws and our customs was proceeding at such amazing speed that whereas at first I had been full of zeal for public life, when I noted these changes and saw how unstable everything was, I became in the end quite dizzy; and though I did not cease to reflect how an improvement could be brought about in our laws and in the whole constitution, yet I refrained from action, waiting for the proper time (kairos). At last I came to the conclusion that all existing states are badly governed and the condition of their laws practically incurable, without some miraculous remedy and the assistance of fortune; and I was forced to say, in praise of true philosophy, that from her height alone was it possible to discern what the nature of justice is, either in the state or in the individual, and that the ills of the human race would never end until either those who are sincerely and truly lovers of wisdom come into political power, or the rulers of our cities, by the grace of God (theia moira), learn true philosophy. ${ }^{4}$

In this excerpt, Plato provides a clear testimony about the troubled times after the Athenian defeat and how democracy was replaced by the Thirty Tyrants. He then explains how, eventually, democracy was restored. But it is more than a simple historical testimony. Instead of simply describing facts, Plato also reflects on the way to find a new and better political system for Athens. His reflection can be described according to three main aspects.

First, Plato's political thought is connected to history. His thought does not consist of an abstract reflection about what should be the best political regime in theory, but rather in researching what could be the best regime for Athens according to the historical, political, and military context of his time. This explains why Plato was, at the beginning, in favor of the Thirty Tyrants because he thought they would be better than the democratic regime that led Athens to its loss. It also explains why Plato had been opposed to the Thirty Tyrants after he realized that this regime was way worse than democracy by spreading stasis within

\footnotetext{
4 Seventh Letter, 324b-326b. Plato, Complete Works, ed. John M. Cooper (Hackett Pub Co, 1997).
} 
the city. But when democracy was reestablished, this system sentenced Socrates to death, leading Plato to step back from any political ambitions and to wait for better circumstances.

This fact is tightly connected to the definition of a criterion for his political project: justice. Plato is not moved by selfish ambition of opportunism, rather he genuinely wants to find a way to put an end to the conflicts ravaging the city. Any attempt at political revolution will need to be based on justice as a normative principle able to reestablish peace within the city. Therefore, this principle will need to be clearly defined and explained by Plato.

The third aspect of Plato's reflection consists of the elaboration of a set of philosophical concepts in order to try to solve the problem of stasis. There are two major concepts here: kairos and theia moira. Kairos can be defined as the art of the conjuncture for the statesman. A political action will be successful only if it is realized in the right context (for instance: having enough people on your side to support you) and at the right time. However, it is very difficult to find such conditions because Plato pictures Athens as "practically incurable." A large part of the statesmen and of the citizens had been deeply corrupted by the previous political regimes. Therefore, to reform the city, Plato will first need to conceive of a political model able to protect the citizens from injustice. But how can a corrupted city producing corrupted people save itself without any virtuous and uncorrupted men able to reform it? To meet this challenge, Plato proposes the philosopher kings hypothesis at the end of the text. According to this hypothesis, a virtuous government able to restore justice within the city can appear only if philosophers become statesmen or if statesmen become philosophers. This radical change is only possible, according to Plato, thanks to the "grace of God" ("théia moira") as some divine help. This divine intervention allows gifted men to resist the ambient corruption of the historical city and realize that the city needs to be ruled according to justice and philosophy in order to put an end to stasis.

This analysis of the beginning of the Seventh Letter shows that Plato has been completely aware of the challenge caused by the stasis in Athens and that he has tried to find some way to reestablish peace and justice within the city. However, what is Plato's exact conception of justice? How can this conception of justice be instantiated? To sum up: is Plato's philosophy really able to meet the challenge presented by the historical and political crisis of his time?

\section{Plato's Republic as a response to the problem of stasis}

In the second step of this paper, I will discuss Plato's response to the problem of stasis in the Republic. First, I will show how stasis is conceived in the Republic and how Plato plans to fight it. Then, I will point out some problems in Plato's answer to stasis.

\section{A. Stasis in the Republic:}

In the Republic, Plato defines stasis by opposition to polemos in the following text: It seems to me that as we have two names, "war" (polemos) and "civil war" (stasis), so there are two things and the names apply to two kinds of disagreements arising in them. The two things I'm referring to are what is one's own and akin, on the one hand, and what's foreign and strange, on the other. The name "civil war" applies to hostilities with one's own, while "war" applies to hostilities with strangers.

That's certainly to the point.

Then see whether this is also to the point: I say that the Greek race is its own and akin, but is strange and foreign to barbarians.

That's right. 
Then when Greeks do battle with barbarians or barbarians with Greeks, we'll say that they're natural enemies and that such hostilities are to be called war. But when Greeks fight with Greeks, we'll say that they are natural friends and that in such circumstances Greece is sick and divided into factions and that such hostilities are to be called civil war.

I, at any rate, agree to think of it that way. ${ }^{5}$

Plato's position is quite clear. Only polemos as conflict between Greeks and Barbarians is acceptable. Stasis has to be, by all means, avoided. However, Plato does not simply rewrite what he has already discussed in the Seventh Letter previously mentioned. This text shows that the goal of the Republic is to get rid of stasis by proposing a new model for the organization of the city. This new model would then be capable of establishing justice and bringing back peace as a harmonious balance between the different parts of the city (because, on the contrary, stasis is what creates some sort of disharmony in the city). Therefore, to get rid of stasis, Plato will need to determine how to establish justice as a fair balance between the different parts of the city.

Plato tried to meet this challenge in the Republic (370c) by claiming that justice within the city can happen only if the citizens perform the task they are the best suited for. In fact, justice is, for Plato, the institution of a harmony between all the parts of the city. Consequently, Plato divides the city into three parts according to the natural capacities of its citizens: the rulers, the guardians and the auxiliaries. This model is called kallipolis. Those who belong to the class of guardians are well-trained warriors and athletes, excellent at mastering fighting techniques and, above all, completely devoted to defending the city against enemies from the outside in order to guarantee justice. In other words, they will only practice polemos and not stasis.

In the context of the Republic, Plato's solution seems ambiguous. First, it is surprising to claim to assure peace by creating a class of warriors. Then, Plato seems to picture these guardians according to standards that no longer exist at his time. He also compares these warriors to heroes from archaic and Homeric times. In this sense, does Plato really want to try to solve the political and military problems of his time? Or does he rather reuse an old and perhaps obsolete conception of war and warriors?

\section{B. The ambiguities of Plato's response to stasis}

Plato's hypothesis to avoid stasis by creating a class of citizen dedicated to the defense of the city is puzzling because it is related to references and codes, which seem to be obsolete at the beginning of the fourth century BC. To support this objection, let's have a look at ancient Greek history. According to Claude Mossé, Plato's time was characterized by the extension of the military duties to the lower classes of citizens and by the growing significance of naval warfare. ${ }^{6}$ In fact, war at the beginning of the fourth century $\mathrm{BC}$ was no longer the privilege of a few citizens or a way for men to demonstrate their capabilities, but rather a way for the city to establish its dominance over its enemies. This change coincides with the rise of naval warfare in the Greek world and the mobilization of the poorest citizens during conflicts (for instance, the poorest citizens were chained in galleys). On the contrary, there is no such phenomenon in Plato's Republic. War is not for everybody but only for the guardians who demonstrate the best qualities for it.

\footnotetext{
${ }^{5}$ Republic, 470b-d. Plato, Complete Works.

${ }^{6}$ See Claude Mossé, Politique et société en Grèce ancienne (Paris: Aubier, 1995), 180.
} 
Moreover, Plato refers to the Homeric tradition to describe these guardians. For instance, Plato compares the honors given to guardians to honors given to Achilles in the Iliad (VII, 321-322):

Indeed, according to Homer too, it is just to honor in such ways those young people who are good, for he says that Ajax, when he distinguished himself in the battle, "was rewarded with the long cut off the backbone." And that's an appropriate honor for a courageous young man, since it will both honor him and increase his strength. ${ }^{7}$

In fact, it is possible to think that Plato, instead of trying to create a new model of warrior able to deal with contemporary problems of stasis, prefers to refer to old models potentially outdated in post-Peloponnesian War Athens.

To sum up, Plato, in order to solve the problem of stasis, suggests a highly questionable solution because it is deeply rooted in ancient and potentially obsolete conceptions of warfare. This fact is crucial because it deals with the ability of Plato's philosophy to address the problem of stasis. Has Plato failed? Or is it possible to find a way to explain his choice in the Republic? Let's see how it is possible to defend Plato's position.

\section{Strength and weakness of Plato's position about stasis}

Even if Plato was really good at observing and describing the historical situation of his time, his plan to reform Athens is questionable since he uses models from a bygone age. However, is it possible to find a way to explain Plato's position?

A Homeric and archaic legacy was identified in Plato's conception of war in the Republic. However, some parts of this dialogue show that Plato is not fully in favor of this legacy and this is why his position needs to be carefully analyzed. There are some clues in the dialogue showing that Plato's reference to the Homeric and archaic tradition is not unconditional.

First, Plato has, especially in the second and the third books of the Republic, a very critical attitude towards the Homeric tradition. For instance, when Socrates and his companions examine what kind of models should be used for the education of children, they condemn the Homeric tradition because it shows men acting cowardly or lacking courage (387d-388d). It is easy to understand that such models cannot be used to raise the children who will become the guardians of the city. Therefore, Plato's reference to the Homeric tradition has to be considered carefully. Surely, the guardians are compared to Homeric heroes and share values with the warriors of the Homeric times, but they are not Homeric warriors themselves.

Then, there is another clue showing that Plato is quite critical toward the Homeric and archaic tradition: Homer's heroes and Plato's guardians do not share the same motivations. Homeric warriors are motivated by kléos. Kléos is a major element of the Homeric heroic code. It represents the reputation of courage and bravery that the warrior aims to get by exposing his life to danger on the battlefield. ${ }^{8}$ It is essentially an individual phenomenon. ${ }^{9}$ Kléos is the supreme honor that a warrior can obtain. The warrior fights for his own pride, for himself, and not for the community. On the contrary, in Plato's Republic, the guardians live in community and their task is to maintain balance, peace, and happiness within the different parts of the city as stated by Socrates in the following excerpt:

\footnotetext{
7 Republic 468d. Plato, Complete Works.

8 See Hans Wees, Greek Warfare : Myths and Realities (London: Duckworth, 2004), 160, note 22.

9 See Claude Mossé, La Grèce Archä̈que d'Homère À Eschyle (Paris: Seuil, 1984), 38.
} 
In establishing our city, we aren't aiming to make anyone group outstandingly happy but to make the whole city so, as far as possible. We thought that we'd find justice most easily in such a city and injustice, by contrast, in the one that is governed worst and that, by observing both cities, we'd be able to judge the question we've been inquiring into for so long. We take ourselves, then, to be fashioning the happy city, not picking out a few happy people and putting them in it, but making the whole city happy. ${ }^{10}$

The Platonic project aims to establish happiness in the city through justice and not to valorize individual pride or kléos. More generally, Plato does not refer to the Homeric tradition in a nostalgic or naïve way. The guardians are dedicated to defending the city against internal dissension (stasis) and enemies from the outside (polémos). By creating such a military class, Plato's goal was not to valorize war and conflict for their own sake, but only to respond to a problem of his time: the danger of stasis. But why has Plato chosen to refer to the Homeric tradition if he is also quite critical towards it? In my opinion, Plato refers to the Homeric tradition more to make his view understandable to the largest audience than to pay an unconditional and naïve tribute to Homer. It is a way to keep a continuum between the old models and the new models that he wants to create. Plato is aware that any attempt of brutal revolution in the city will lead to disaster just as the Thirty Tyrants did. Restoring peace and balance within the city is possible only through reform, and not war, as Plato warns anybody willing to change the city through a revolution in the Seventh Letter:

Let him not use violence upon his fatherland to bring about a change of constitution. If what he thinks is best can only be accomplished by the exile and slaughter of men, let him keep his peace and pray for the welfare of himself and his city. ${ }^{11}$

Plato's political philosophy here is deeply connected to the problems of its time. Surely, the Peloponnesian War and its consequence, the Thirty Tyrants regime, were catastrophic for Athens. However, forcing people into a change of regime, even if this regime is theoretically better, will doubtlessly lead to disaster and chaos.

\section{Conclusion}

In this paper, I have tried to show how Plato had taken into consideration the problem of stasis and tried to solve it in his political philosophy.

To achieve this goal, Plato developed a new model of city (the kallipolis) based on a strict division of tasks between three main categories of citizens supposed to guarantee justice within the city. One of these categories, the guardians, was dedicated to the defense of the city and the preservation of peace and justice.

However, the definition of this class of guardians was widely based on a Homeric and archaic tradition and legacy. This aspect is problematic and contradictory. How is it possible for Plato to try to solve a problem caused by the historical circumstances of his time by reusing values and examples related to a bygone era? The key is that Plato refers to an old tradition to discuss his political project and he does not unconditionally praise obsolete values. On the contrary, he tries to establish a continuum between ancient and contemporary times. Proposing such a solution elsewhere would have been fatal for his project of

\footnotetext{
10 Republic, 420c. Plato, Complete Works.

11 Seventh Letter, 331d. Plato, Complete Works.
} 
renovation of Athens's political system and would have been a failure for his desire to establish peace and happiness in the city.

\section{Bibliography:}

Mossé, Claude. La Grèce Archaïque d'Homère À Eschyle. Paris: Seuil, 1984. Politique et société en Grèce ancienne. Paris: Aubier, 1995.

Orrieux, Claude, and Pauline Schmitt Pantel. Histoire Grecque. PUF, 2004.

Plato. Complete Works. Edited by John M. Cooper. Hackett Pub Co, 1997.

Romilly, Jacqueline de. "Guerre et Paix Entre Cités." In Problèmes de La Guerre En Grèce Ancienne, edited by Jean-Pierre Vernant. Seuil, 1999.

Solmsen, Friedrich. "Review of Plato's Seventh Letter.” Gnomon 41, no. 1 (1969): 29.

Wees, Hans. Greek Warfare: Myths and Realities. London: Duckworth, 2004.

The PJCV Journal is published by Trivent Publishing. 